\title{
Dietary live yeast (Debaryomyces hansenii) provides no advantages in tropical gar, Atractosteus tropicus (Actinopterygii: Lepisosteiformes: Lepisosteidae), juvenile aquaculture
}

\author{
Iris Adriana HERNÁNDEZ-LÓPEZ1, Dariel TOVAR-RAMÍREZ², \\ Susana DE LA ROSA-GARCÍA ${ }^{1}$, Carina Shianya ÁLVAREZ-VILLAGÓMEZ ${ }^{1}$, \\ Gloria Gertrudys ASENCIO-ALCUDIA ${ }^{1}$, Talhia MARTÍNEZ-BURGUETE ${ }^{1}$, \\ Mario Alberto GALAVIZ ${ }^{3}$, Rocío GUERRERO-ZÁRATE ${ }^{1}$, Rafael MARTÍNEZ-GARCÍA ${ }^{1}$, \\ Emyr Saúl PEÑA-MARÍN ${ }^{1,4^{*}}$, Carlos Alfonso ÁLVAREZ-GONZÁLEZ ${ }^{1 *}$
1 Laboratorio de Acuicultura Tropical, División Académica de Ciencias Biológicas (DACBiol), Universidad Juárez Autónoma de Tabasco (UJAT), Villahermosa, Tabasco, Mexico
2 Laboratory of Comparative Physiology and Functional Genomics, Northwest Biological Research Center (CIBNOR), La Paz, Mexico
3 Faculty of Marine Sciences, Autonomous University of Baja California (UABC), Ensenada BC, México
4 National Council for Science and Technology (CONACyT), CDMX, Mexico \\ http://zoobank.org/525D9949-1296-477F-971A-115103EA07D6
}

Corresponding authors: Carlos Alfonso Álvarez-González (alvarez_alfonso@hotmail.com),Emyr Saul Peña-Marín (ocemyr@yahoo.com.mx)

Academic editor: Jolanta Kielpińska • Received 28 August 2020 • Accepted 6 March 2021 • Published 13 September 2021

Citation: Hernández-López IA, Tovar-Ramírez D, De La Rosa-García S, Álvarez-Villagómez CS, Asencio-Alcudia GG, MartínezBurguete T, Alberto Galaviz M, Guerrero-Zárate R, Martínez-García R, Peña-Marín ES, Álvarez-González CA (2021) Dietary live yeast (Debaryomyces hansenii) provides no advantages in tropical gar, Atractosteus tropicus (Actinopterygii: Lepisosteiformes: Lepisosteidae), juvenile aquaculture. Acta Ichthyologica et Piscatoria 51(3): 311-320. https://doi.org/10.3897/aiep.51.67095

\begin{abstract}
Tropical gar, Atractosteus tropicus Gill, 1863, is an ancient freshwater fish that is commercially cultivated in southern Mexico. Currently, there is a specific diet for its culture; however, the addition of probiotics has not been investigated. The objective of this study was to evaluate the supplementation of live yeast Debaryomyces hansenii for A. tropicus juveniles on growth, productive parameters, survival, somatic index, digestive enzyme activity, and immune system gene expressions (interleukin 10, il-10, Transforming growth factor $\beta 1, \operatorname{tg} f-\beta 1$, and $\beta 2$ microglobulin, $b 2 \mathrm{~m})$. Three experimental diets increased the dose of live yeast $(0.5$, 1.0, and $1.5 \% ; 10^{14}, 10^{15}$, and $10^{16} \mathrm{CFU} g$ diet $^{-1}$, respectively) and a control diet (CD; without yeast) were designed. Daily weight gain and specific growth rate were higher in fish fed with $\mathrm{CD}$ and $0.5 \%$ D. hansenii. High activities of trypsin, chymotrypsin LAP, and $\alpha$-amylase, as well as overexpression of $i l-10$ in the spleen, were detected in fish feed $0.5 \% D$. hansenii. The inclusion of $D$. hansenii had no positive effect on aquaculture for $A$. tropicus, lower doses should be tested to optimize the diet.
\end{abstract}

\section{Keywords}

digestive physiology, enzymes, gar, immune system, nutrition, probiotics

\footnotetext{
* Both authors contributed equally.
}

Copyright Hernández-López et al. This is an open access article distributed under the terms of the Creative Commons Attribution License (CC BY 4.0), which permits unrestricted use, distribution, and reproduction in any medium, provided the original author and source are credited. 


\section{Introduction}

Fish production worldwide is facing challenges related to disease control and nutrition improvement through food optimization, where probiotics show beneficial effects for the host, showing several advantages in the aquaculture production (Akhter et al. 2015), including the immune system, maturation of the digestive system, and host metabolism (Hai 2015; Angulo et al. 2017) and antagonistic capacity to possible pathogenic organisms (Navarrete and Tovar-Ramírez 2014). Yeast Debaryomyces hansenii is a halotolerant, non-pathogenic ubiquitous yeast capable of growing and proliferating in a variety of environments, including marine fish (Raggi et al. 2014) and freshwater fish gut (Andlid et al. 1995) and several studies demonstrate positive effects of $D$. hansenii on digestive maturation, increase in survival, the activity of pancreatic and luminal digestive enzymes, increase in resistance to infection by the improvement of immunity and resistance as well to generate a positive effect on the antioxidative status in several fish species fed yeast such as European sea bass, Dicentrarchus labrax (Linnaeus, 1758); gilthead seabream, Sparus aurata Linnaeus, 1758; leopard grouper, Mycteroperca rosacea (Streets, 1877), to name just a few (Tovar-Ramírez et al. 2004, 2010; Reyes-Becerril et al. 2008; Reyes-Becerril et al. 2011). Moreover, the inclusion of probiotics has been evaluated through the immune system gene expression such as interleukins, where Il-10 stands out, which is an immunosuppressive cytokine that prevents immune-mediated damage to the host by dampening inflammatory responses of the immune response (Howes et al. 2014), the $\beta 2 \mathrm{mi}-$ croglobulin $(b 2 m)$ is classified as part of the set of the immunoglobulin superfamily (IgSF) and play important roles in the adaptive immune system (Chen et al. 2010). The immunological function of $b 2 m$ is to assist classical major histocompatibility complex (MHC) class I (i.e., MHC-I) molecules in assembling endogenous antigen peptides, forming a trimolecular complex (i.e., pMHC-I) and then presenting them to the surface of antigen-presenting cells (APCs); through interaction with T cell receptors (TCRs), specific cytotoxic T lymphocyte (CTL) immunity is thus induced (Flajnik and Kasahara 2001; Li et al. 2020), and the transforming growth factor $\beta 1$ (tgf- $\beta 1)$, which is an important multifunctional cytokine involved in the regulation of cell proliferation, differentiation, survival, migration, and apoptosis under physiological and pathological conditions (Qi et al. 2016). For example, tgf- $\beta 1$ acts as an immunosuppressive mediator and inhibits nitric oxide production in TNF- $\gamma$-activated macrophages in fish (Wang et al. 2017). For instance, the positive effects and benefits of $D$. hansenii are well known; however, beneficial effects depend on the supplemented concentration (Hai 2015), where overdosing or underdosing results in lower efficacy and unnecessary costs, with low efficiency of the probiotic (Sharifuzzaman and Austin 2017). Therefore, the evaluation of the possible impact of probiotic inclusion through the understanding of physiological and metabolic changes is part of a compressive understanding of the new emerging aquaculture species (Angulo et al. 2020).

Tropical gar, Atractosteus tropicus Gill, 1863, is an ancestral, carnivorous, freshwater fish species native to the south-eastern Mexico and Central America that possess ecological, biological, and economic importance (Márquez-Couturier and Vázquez-Navarrete 2015). Recently, this species has been used as a nutritional fish model, with several nutritional studies focused on the characterization of digestive enzymes during larval and juvenile stages (Guerrero- Zárate et al. 2014; Frías Quintana et al. 2015), development of microparticulate and microencapsulated diets for larvae (Saenz de Rodrigáñez et al. 2018), the inclusion of starch sources (Frías-Quintana et al. 2016, 2017), lipogenic metabolism characterization (Jiménez-Martínez et al. 2019), among others. Recently, Nieves-Rodríguez et al. (2018) and Nájera-Arzola et al. (2018) evaluated $\beta$-glucans and mannan oligosaccharides during the juvenile stage in A. tropicus, finding positive effects on growth performance, digestive enzymes activity, and immune system. The objective of this study was to evaluate the supplementation of live yeast $D$. hansenii for $A$. tropicus juveniles on growth, productive parameters, survival, somatic index, digestive enzyme activity, and gene expressions of $i l-10$, $\operatorname{tgf}-\beta 1$, and $b 2 m$.

\section{Material and methods}

\section{Juveniles rearing}

Tropical gar juveniles were obtained from the División Académica de Ciencias Biológicas (DACBiol) from Universidad Juárez Autónoma de Tabasco (UJAT). Spawning was induced using a female and three tropical gar males. The larval development was carried out according to previously described methodologies by Saenz-Rodrigáñez et al. (2018). At the required size $(0.18 \pm 0.01 \mathrm{~g})$, the organisms were used for the experimental.

\section{Probiotic yeast and cell viability}

Yeast $D$. hansenii strain CBS 8339 was provided by CIBNOR, S.C. This strain was isolated from the trout intestine (Andlid et al. 1995) and was produced according to the protocol of Tovar et al. (2002). The strain was cultured in yeast peptone dextrose (YPD, Sigma-Aldrich) at $25^{\circ} \mathrm{C}$ with constant aeration until the early stationary phase (24 h). The cell suspension was centrifuged (1000 $g$ for 5 min at $4^{\circ} \mathrm{C}$ ) and the recovered pellet was immediately incorporated into the diet ingredients in different concentrations as shown in Table 1 . The viability of the yeast biomass was determined as colony forming units (CFU) 
Table 1. Ingredient content, proximate analysis, and gross energy content of the experimental diets supplemented with $D e-$ baryomyces hansenii.

\begin{tabular}{|c|c|c|c|c|}
\hline \multirow[t]{2}{*}{ Ingredient [\%] } & \multicolumn{4}{|c|}{ Treatment (Diet) } \\
\hline & CD & D1 & D2 & D3 \\
\hline Fish meal $^{a}$ & 40.7 & 40.7 & 40.7 & 40.7 \\
\hline Renderer meal $^{\mathrm{a}}$ & 30.0 & 29.5 & 29.0 & 28.5 \\
\hline Corn starch ${ }^{\mathrm{b}}$ & 15.4 & 15.4 & 15.4 & 15.4 \\
\hline Fish oil ${ }^{\mathrm{a}}$ & 6.9 & 6.9 & 6.9 & 6.9 \\
\hline Soybean lecithin ${ }^{\mathrm{c}}$ & 4.0 & 4.0 & 4.0 & 4.0 \\
\hline Grenetin $^{f}$ & 2.0 & 2.0 & 2.0 & 2.0 \\
\hline Vitamin $c^{d}$ & 0.5 & 0.5 & 0.5 & 0.5 \\
\hline Vitamin and mineral premix ${ }^{\mathrm{e}}$ & 0.5 & 0.5 & 0.5 & 0.5 \\
\hline D. hansenii concentration $\%$ and & 0.0 & 0.5 & 1.0 & 1.5 \\
\hline CFU g of diet ${ }^{-1}$ & 0.0 & $6.3 \times 10^{14}$ & $1.2 \times 10^{15}$ & $1.9 \times 10^{16}$ \\
\hline \multicolumn{5}{|l|}{ Proximate composition [\%] } \\
\hline Energy $\left[\mathrm{kj} \mathrm{g}^{-1}\right]$ & 17.7 & 17.7 & 17.7 & 17.7 \\
\hline Protein & 43.6 & 44.2 & 43.3 & 43.0 \\
\hline Ether extract & 15.0 & 14.8 & 14.9 & 15.1 \\
\hline Ash & 15.0 & 14.9 & 14.6 & 15.2 \\
\hline $\mathrm{NFE}^{1}$ & 26.4 & 26.1 & 27.1 & 26.7 \\
\hline
\end{tabular}

$\mathrm{CD}=$ control diet, D1, D2, and D3 are experimental diets featuring increasing content of $D$. hansenii; Renderer meal is a poultry by-product; ${ }^{2}$ Marine and agricultural proteins

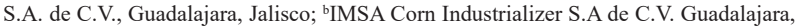
Jalisco, México; 'Pronat Ultra, Mérida, Yucatán, México; dROVIMIX® STAY-C® 35 Vitamins - Products - DSM México, Guadalajara, Jalisco, México and ${ }^{\circ}$ Trouw Nutrition México S.A. de C.V. (by courtesy). 'D'gari Productos alimenticios y dietéticos Relámpago, Tlalpan, Edomex, Mexico. NFE ${ }^{1}=$ Nitrogen-free extract: $100-(\%$ protein $-\%$ ether extract $-\%$ ash); $\mathrm{CFU}=$ colony forming units.

by plating on YPD plates supplemented with antibiotics (chloramphenicol, $1 \mathrm{mg} \mathrm{L}^{-1}$; polymyxin sulfate $\mathrm{B}, 1.6 \mathrm{mg}$ $\mathrm{L}^{-1}$; amoxicillin, $2.5 \mathrm{mg} \mathrm{L}^{-1}$, Sigma-Aldrich). The plates were incubated for $48 \mathrm{~h}$ at $30^{\circ} \mathrm{C}$ before colony counting.

After 35 days of culture, yeast cell counts were taken using the trypan blue dye exclusion test to also measure the cell viability, and percent survival was calculated using the total viable yeast cell. A 1:10 dilution $(\mathrm{w} / \mathrm{v})$ was performed and mix $500 \mu \mathrm{L}$ of $0.4 \%$ (w/v) trypan blue (Sigma, Aldrich) and $500 \mu \mathrm{L}$ of dilution. Allow mixture to incubate for $3 \mathrm{~min}$ at room temperature. $10 \mu \mathrm{L}$ of the dilution was taken to load the Neubauer chamber, and the microscope was observed in $400 \times$ magnification, where live cells (unstained) and dead cells (stained blue) were counted and the viable cell [\%] was determined by $\mathrm{mL}$ with the following equation:

Viable cells $[\%]=\frac{\text { Total number of viable cells per aliquot }[\mathrm{mL}]}{\text { Total number of cells per aliquot }[\mathrm{mL}]} \times 100$

\section{Experimental design and diet manufacture}

The experiment designed consisted of four formulated diets, using diet reported by Frías-Quintana et al. (2016) a control diet (CD, without $D$. hansenii) and three diets supplemented with high increasing levels of yeast $D$. hansenii (D1 with $0.5 \%$; D2 with 1.0 and D3 with $1.5 \%$ of D. hansenii) as shown in Table 1, being isocaloric and isolipidic. The experimental diets were manufactured following the protocol proposed by Alvarez-González et al. (2001). The diets obtained were dried at $40^{\circ} \mathrm{C}$ for $12 \mathrm{~h}$. The experiment was performed in $70 \mathrm{~L}$ plastic tanks, connected to a recirculation system with a settler and biofilter, randomizing 20 juveniles per tank. All treatments were performed in triplicate. Water quality was monitored daily (mean \pm standard deviation, SD), with mean values of temperature $\left(26.9 \pm 0.4^{\circ} \mathrm{C}\right)$ and dissolved oxygen $\left(5.1 \pm 0.4 \mathrm{mg} \mathrm{L}^{-1}\right)$ determined by an oximeter (YSI 85; OH), and $\mathrm{pH}(7.2 \pm$ 0.1) with a potentiometer (HANNA HI991001, Romania).

\section{Growth, somatic index, and sampling}

Biometrics was performed every 15 days during 45 days of experimentation, recording wet weights and total length. At the end of the experiment, three juveniles per tank (nine per treatment) were euthanized with an overdose of clove oil dissolved in ethyl alcohol in 1:1 ratio and then dissected to record individual organ weight (stomach, intestine, and liver); additionally, mesenteric fat for each fish was removed and intestine length (from the pylorus until the anus) was measured. For digestive enzyme activity analysis (from the same fishes), the stomach and intestine were removed, rinsed with distilled water, and frozen at $-80^{\circ} \mathrm{C}$ until the enzymatic process. For gene expression analysis, two fish per tank (six per treatment) were sacrificed. The liver, intestine, and spleen samples were fixed in RNA Later ${ }^{\circledR}$ (Thermo Fisher Scientific, Waltham, MA, USA) and frozen at $-80^{\circ} \mathrm{C}$ for future treatment.

Based on the data obtained from feed consumption, growth, weight, and survival the following parameters and somatic indexes were calculated:

$$
\begin{gathered}
\text { Daily weight gain }\left(\mathrm{DWG}\left[\mathrm{g} \mathrm{Day}^{-1}\right]\right)=\frac{\text { Final biomass }[\mathrm{g}]-\text { Initial biomass }[\mathrm{g}]}{\text { Number of days }} \\
\text { Specific growth rate }\left(\mathrm{SGR}\left[\% \mathrm{Day}^{-1}\right]\right)=\frac{\text { Ln final mean weight }- \text { Ln initial mean weight }}{\text { Number of days }} \times 100 \\
\text { Feed conversion rate }(\mathrm{FCR})=\frac{\text { Total food consumed }[\mathrm{g}]}{\text { Final biomass }[\mathrm{g}]-\text { Initial biomass }[\mathrm{g}]} \\
\text { Protein conversion rate }(\mathrm{PER})=\frac{\text { Final biomass }[\mathrm{g}]-\text { initial biomass }[\mathrm{g}]}{\text { Protein ingested }[\mathrm{g}]} \\
\text { Survival }\left(\mathrm{S}[\%]=\frac{\text { Final number of organisms }}{\text { Initial number of organisms }} \times 100\right.
\end{gathered}
$$




$$
\begin{gathered}
\text { Hepatosomatic index }(\mathrm{HSI})=\frac{\text { Liver weight }[\mathrm{g}] \times 100}{\text { Body weight }[\mathrm{g}]} \\
\text { Viscerosomatic index }(\mathrm{VSI})=\frac{\text { Viscera weight }[\mathrm{g}] \times 100}{\text { Body weight }[\mathrm{g}]} \\
\text { Mesenteric fat index }(\mathrm{MSI})=\frac{\text { Mesenteric fat weight }[\mathrm{g}] \times 100}{\text { Body weight }[\mathrm{g}]} \\
\text { Condition factor }(\mathrm{CF})=\frac{\text { Body weight }[\mathrm{g}]}{\text { Body length }[\mathrm{cm}]^{3}} \times 100 \\
\text { Relative intestine size }(\mathrm{RIL})=\frac{\text { Intestine length }[\mathrm{cm}] \times 100}{\text { Body length }[\mathrm{cm}]}
\end{gathered}
$$

\section{Digestive enzymes techniques}

The stomach and intestine were homogenized separately in distilled water in 1:5 ratio (w:v) with an Ultra Turrax (IKA T18 basic, Wilmington, USA), under cold conditions $\left(4^{\circ} \mathrm{C}\right)$, then centrifuged at $16000 \mathrm{~g}$ by $15 \mathrm{~min}$ at $4^{\circ} \mathrm{C}$ and the supernatant was recovered to be stored at $-80^{\circ} \mathrm{C}$ until the analyzes were performed. Soluble protein concentration in the stomach and intestine multienzymatic extracts were determined with Bradford (1976) technique using bovine serum albumin as the standard protein.

Acid protease activity (stomach homogenate) was determined according to Anson (1938) using hemoglobin $(1 \%)$ as a substrate in $100 \mathrm{mmol} \mathrm{L}^{-1}$ glycine- $\mathrm{HCl}$ buffer at $\mathrm{pH} 2$, where the absorbance of the reaction was measured at $280 \mathrm{~nm}$. Alkaline protease activity (intestine homogenate) was determined according to Walter (1984) using casein $(1 \%)$ as substrate in buffer Tris-HCl $100 \mathrm{mmol} \mathrm{L}^{-1}$, $10 \mathrm{mmol} \mathrm{L}^{-1} \mathrm{CaCl}_{2}$ at $\mathrm{pH} \mathrm{9}$, where the absorbance of the reaction was measured at $280 \mathrm{~nm}$. Trypsin activity was determined according to Erlanger et al. (1961) using $1 \mathrm{mmol}$ $\mathrm{L}^{-1}$ BAPNA (N $\alpha$-Benzoyl-DL-arginine-p-nitroanilide) as substrate, dissolved in $50 \mathrm{mmol} \mathrm{L}^{-1}$ Tris- $\mathrm{HCl}$ buffer,

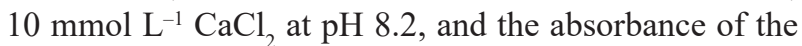
reaction was measured at $410 \mathrm{~nm}$. The chymotrypsin activity was determined according to Hummel (1959) using $\mathrm{N}$-benzoyl-L-tyrosine ethyl ester (BTEE) $5 \mathrm{mmol} \mathrm{L}^{-1}$ as the substrate dissolved in Dimethyl sulfoxide (DMSO) in $100 \mathrm{mmol} \mathrm{L}^{-1}$ Tris buffer, $100 \mathrm{mmol} \mathrm{L}^{-1} \mathrm{CaCl}_{2}$ at $\mathrm{pH} 7.8$, and the absorbance was determined at $256 \mathrm{~nm}$. The leucine aminopeptidase (LAP) activity was determined according to Maroux et al. (1973) using leucine p-nitroanilide $\left(1.2 \mathrm{mmol} \mathrm{L}^{-1}\right)$ as substrate in $50 \mathrm{mmol} \mathrm{L}^{-1}$ sodium phosphate buffer at $\mathrm{pH} 7.2$, and the absorbance was measured at $405 \mathrm{~nm}$. The $\alpha$-amylase activity was determined according to Robyt and Whelan (1968), using potato starch $(2 \%)$ as substrate, dissolved in $100 \mathrm{mmol} \mathrm{L}^{-1}$ citrate-phosphate buffer and $50 \mathrm{mmol} \mathrm{L}^{-1}$ sodium chloride at $\mathrm{pH} 7.5$, and reducing sugars were measured at $600 \mathrm{~nm}$. The lipase activity was determined according to Versaw et al. (1989), using $\beta$-naphthyl caprylate $\left(200 \mathrm{mmol} \mathrm{L}^{-1}\right)$ as a substrate dissolved in buffer $50 \mathrm{mmol} \mathrm{L}^{-1}$ Tris- $\mathrm{HCl}$ and $100 \mathrm{mmol} \mathrm{L}^{-1}$ sodium cholate at $\mathrm{pH} 7.2$, and the absorbance was measured at $540 \mathrm{~nm}$. The alkaline phosphatase activity was determined according to Bergmeyer (1974), 4-nitrophenyl phosphate $(2.4 \%)$ as substrate, dissolved in buffer $100 \mathrm{mmol} \mathrm{L}^{-1}$ glycine- $\mathrm{NaOH}$ at $\mathrm{pH} 10.1$, and the absorbance was measured at $405 \mathrm{~nm}$. All the techniques were performed at $37^{\circ} \mathrm{C}$.

One unit (U) of enzymatic activity was defined as the amount of enzyme that produced $1 \mu \mathrm{mol}$ of product released per minute. Total activity was calculated applying equation

$$
\text { Total activity [Units } \left.\mathrm{mL}^{-1}\right]=\frac{\Delta \mathrm{abs} \times \text { reaction final volume }[\mathrm{mL}]}{\mathrm{MEC} \times \text { time }[\mathrm{min}] \times \text { extract volume }[\mathrm{mL}]}
$$

where $\Delta$ abs represent the increase in absorbance, and MEC represents the molar extinction coefficient.

Specific digestive enzyme activity was calculated using equation

$$
\mathrm{U} \text { mg protein }{ }^{-1}=\frac{\text { Units } \mathrm{mL}^{-1}}{\mathrm{mg} \text { protein } \mathrm{mL}^{-1}}
$$

where $\mathrm{mg}$ protein ${ }^{-1}$ is determined by Bradford method (1976).

\section{RNA isolation and Quantitative Reverse Transcription PCR (RT-qPCR)}

Total RNA from each tissue (liver, intestine, and spleen) was extracted individually using TRIzol Reagent (Invitrogen, Carlsbad, CA, USA) according to the manufacturer's protocol. The concentration and purity of the RNA samples were assessed by the ratio of the absorbance at 260/280 nm using a spectrophotometer (NanoDrop 2000). The RNA integrity of the samples was verified by visualization of $28 \mathrm{~S}$ and $18 \mathrm{~S}$ rRNAs after $1 \%$ agarose gel electrophoresis. The cDNA synthesis was performed using the Improm II Reverse Transcription System (Promega, Madison, WI, USA) following the manufacturer's recommendations. On the ice, $0.5 \mu \mathrm{g}$ of experimental RNA was combined with $1 \mu \mathrm{L}$ of Oligo dT in nuclease-free water for a final volume of $5 \mu \mathrm{L}$. The primer/template mix was thermally denatured at $70^{\circ} \mathrm{C}$ for $5 \mathrm{~min}$ and chilled on ice. Subsequently, $15 \mu \mathrm{L}$ of the reverse transcription reaction mix $\left(5 \times\right.$ reaction buffer, $2 \mathrm{mM} \mathrm{MgCl}_{2}, 0.5 \mathrm{mM}$ dNTPs, $1 \mu \mathrm{L}$ reverse transcriptase, and $20 \mathrm{u}$ ribonuclease inhibitor) was added in a final volume of $20 \mu \mathrm{L}$. The reaction mix was incubated at $25^{\circ} \mathrm{C}$ for 5 minutes following at $42^{\circ} \mathrm{C}$ for $60 \mathrm{~min}$. The synthesized cDNA was diluted $1: 3$ $(\mathrm{v} / \mathrm{v})$ and stored at $-80^{\circ} \mathrm{C}$ until later use.

The RT-qPCR was performed in a CFX96 Real-Time System (BioRad, Hercules, CA, USA) using $10 \mu \mathrm{L}$ of $\mathrm{IQ}^{\mathrm{TM}}$ SYBR Green Supermix (BioRad), $1 \mu \mathrm{L}$ primers mix, and $9 \mu \mathrm{L}$ of diluted cDNA for a final volume of 20 $\mu \mathrm{L}$. The cycles in the RT-qPCR program used was the following: $50^{\circ} \mathrm{C}$ for $2 \mathrm{~min}, 95^{\circ} \mathrm{C} 10 \mathrm{~s}$, followed by 40 
cycles at $95^{\circ} \mathrm{C} 15 \mathrm{~s}$, and $62^{\circ} \mathrm{C} 1 \mathrm{~min}$. As a reference, the gene the elongation factor (efl) was used. Relative gene expression was calculated as fold-change compared with control and calculated by means of the formula $2-\Delta \Delta \mathrm{Ct}$ (Livak and Schmittgen 2001). Design of specific oligonucleotides for Interleukin 10 (il-10), $\beta 2$ microglobulin $(b 2 m)$, Transforming growth factor $\beta 1$ (tgf- $\beta 1)$ were obtained from the $A$. tropicus transcriptome (Martínez-Burguete et al. 2021, Accession: PRJNA395289), shown in Table 2, and Elongation factor (efl) was obtained as previously reported (Jiménez-Martinez et al. 2019).

Table 2. Primers designed for Interleukin 10, $\beta 2$ microglobulin, Transforming growth factor $\beta 1$ and Elongation factor genes for qPCR of Atractosteus tropicus.

\begin{tabular}{lcccc}
\hline Gene name & Symbols & Oligo & Primers sequence (5' $\mathbf{3}^{\prime}$ ) & $\begin{array}{r}\text { Temp. } \\
{\left[{ }^{\circ} \mathbf{C}\right]}\end{array}$ \\
\hline Interleukin 10 & $i l-10$ & $-\mathrm{F}$ & GCTGCCGAAGGTACTTCTCTT & 60.03 \\
& & $-\mathrm{R}$ & GTCTGATAATGGGGAAATCCTG & 59.67 \\
\hline$\beta 2$ & $b 2 m$ & $-\mathrm{F}$ & AAGAACAAGCAGCAGATGGAG & 59.63 \\
microglobulin & & $-\mathrm{R}$ & TTTACATGTCAGGTTCCCAGGT & 60.64 \\
\hline Transforming & $t g f-\beta 1$ & $-\mathrm{F}$ & TTCGATAAGACCAGAGGGGATA & 59.92 \\
growth factor & & $-\mathrm{R}$ & CACACAGCAGTTTTCCATCTTC & 59.78 \\
$\beta 1$ & & & & \\
\hline Elongation & $e f 1$ & $-\mathrm{F}$ & CCTGCAGGACGTCTACAAGATCG & 62.86 \\
factor & & $-\mathrm{R}$ & GACCTCAGTGGTCACGTTGGA & 61.97 \\
\hline
\end{tabular}

\section{Statistical analysis}

Data of growth, productive performance, enzymatic activities, and gene expression were analyzed for postulates of normality (KS) and homoscedasticity (Levene). One way (ANOVA) was performed and a posteriori Tukey test, if required. All tests were carried out using a level of significance of $95 \%$ in the Sigma Plot program (analytical software, AZ, USA).

\section{Results}

Cell viability in all experimental diets was $95.24 \pm 8.90 \%$ at the end of the experiment without differences between treatments $(P>0.05)$. Fish fed with the $\mathrm{CD}$ and $\mathrm{D} 1 \mathrm{ob}-$ tained higher DWG and SGR compared to those fed D2 and D3 $(P<0.05)$. Feeding intake $(\mathrm{FI})$ and survival did not show significant differences between treatments $(P>$ 0.05); additionally, FCR showed a higher value for fish fed D3, while PER showed a lower value for fish fed D3 $(P<0.05)$ (Table 3$)$. The HSI, VSI, and CF did not show significant differences between treatments $(P>0.05)$, while MSI and RIL showed lower value for fish fed D3 (Table 3).

The digestive enzymatic activity showed that acid proteases, total alkaline proteases, and lipase did not present significant differences between treatments $(P>0.05)$, while trypsin and chymotrypsin activities showed the lowest values for fish fed D3. LAP showed lower activity in fish fed D2 and D3 compared with fish fed CD and
Table 3. Productive values, survival and somatic indexes of Atractosteus tropicus juveniles fed with experimental diets supplemented with Debaryomyces hansenii.

\begin{tabular}{lcccc}
\hline Parameter & \multicolumn{4}{c}{ Treatment (Diet) } \\
\cline { 2 - 5 } & CD & D1 & D2 & D3 \\
\hline DWG & $0.070 \pm 0.002^{\mathrm{a}}$ & $0.053 \pm 0.003^{\mathrm{ab}}$ & $0.047 \pm 0.003^{\mathrm{b}}$ & $0.037 \pm 0.001^{\mathrm{c}}$ \\
SGR & $5.19 \pm 0.14^{\mathrm{a}}$ & $4.82 \pm 0.14^{\mathrm{ab}}$ & $4.85 \pm 0.08^{\mathrm{b}}$ & $4.25 \pm 0.28^{\mathrm{b}}$ \\
FCR & $1.83 \pm 0.13^{\mathrm{a}}$ & $1.85 \pm 0.16^{\mathrm{a}}$ & $1.98 \pm 0.14^{\mathrm{a}}$ & $2.58 \pm 0.26^{\mathrm{b}}$ \\
PER & $1.72 \pm 0.18^{\mathrm{a}}$ & $1.25 \pm 0.14^{\mathrm{a}}$ & $1.10 \pm 0.07^{\mathrm{ab}}$ & $0.96 \pm 0.11^{\mathrm{b}}$ \\
S & $90.5 \pm 4.5$ & $81.6 \pm 5.8$ & $86.7 \pm 7.6$ & $76.7 \pm 5.8$ \\
FI & $4.28 \pm 0.47$ & $4.57 \pm 0.32$ & $4.59 \pm 0.36$ & $5.29 \pm 0.97$ \\
HSI & $3.36 \pm 0.52$ & $3.75 \pm 0.47$ & $3.51 \pm 0.52$ & $3.11 \pm 0.45$ \\
VSI & $7.49 \pm 2.24$ & $7.83 \pm 0.89$ & $7.46 \pm 0.42$ & $7.17 \pm 1.75$ \\
MSI & $2.17 \pm 0.34^{\mathrm{a}}$ & $1.52 \pm .0 .38^{\mathrm{ab}}$ & $1.85 \pm 0.49^{\mathrm{ab}}$ & $1.34 \pm 0.65^{\mathrm{b}}$ \\
CF & $0.33 \pm 0.06$ & $0.29 \pm 0.02$ & $0.29 \pm 0.01$ & $0.30 \pm 0.05$ \\
RIL & $33.58 \pm 5.99^{\mathrm{a}}$ & $29.91 \pm 4.64^{\mathrm{ab}}$ & $28.89 \pm 2.32^{\mathrm{ab}}$ & $25.56 \pm 5.55^{\mathrm{b}}$ \\
\hline
\end{tabular}

All weights expressed in grams [g], all lengths in centimeters [cm]; DWG $=$ daily weight gain; $\mathrm{SGR}=$ specific growth rate; $\mathrm{FCR}=$ feed conversion rate; $\mathrm{PER}=$ protein conversion rate; $\mathrm{S}=$ survival; $\mathrm{HSI}=$ hepatosomatic index; $\mathrm{VSI}$ = viscerosomatic index; MSI $=$ mesenteric fat index $; \mathrm{CF}=$ condition factor; $\mathrm{RIL}=$ relative intestine size. Values are mean \pm standard deviation $(n=9)$. Different superscript letters within rows indicate significant $(P<0.05)$

D1 treatments, $\alpha$-amylase showed the lowest activity in fish feed D2, while alkaline phosphatases showed higher activity in fish fed CD $(P<0.05)$ (Table 4$)$.

Table 4. Digestive enzyme activities of Atractosteus tropicus juveniles fed with experimental diets supplemented with $D e$ baryomyces hansenii.

\begin{tabular}{|c|c|c|c|c|}
\hline \multirow{2}{*}{$\begin{array}{c}\text { Total activity } \\
{[\mathrm{U} \text { mg }} \\
\left.\text { protein }^{-1}\right]\end{array}$} & \multicolumn{4}{|c|}{ Treatment (Diet) } \\
\hline & CD & D1 & D2 & D3 \\
\hline $\begin{array}{l}\text { Acid } \\
\text { proteases }\end{array}$ & $299.46 \pm 31.10$ & $403.59 \pm 57.79$ & $305.71 \pm 38.40$ & $305.71 \pm 38.40$ \\
\hline $\begin{array}{l}\text { Alkaline } \\
\text { proteases }\end{array}$ & $38.80 \pm 2.66$ & $44.69 \pm 3.28$ & $30.80 \pm 2.52$ & $29.10 \pm 3.39$ \\
\hline Trypsin & $32.40 \pm 1.76 \mathrm{a}$ & $38.24 \pm 0.51 \mathrm{a}$ & $28.76 \pm 0.41 \mathrm{a}$ & $21.42 \pm 0.30 \mathrm{~b}$ \\
\hline Chymotrypsin & $111.3 \pm 19.8 \mathrm{a}$ & $158.4 \pm 13.0 \mathrm{a}$ & $86.1 \pm 14.8 \mathrm{ab}$ & $62.6 \pm 23.2 \mathrm{~b}$ \\
\hline LAP* & $68.43 \pm 4.08 \mathrm{a}$ & $75.79 \pm 4.57 \mathrm{a}$ & $46.27 \pm 0.82 b$ & $44.84 \pm 1.22 \mathrm{~b}$ \\
\hline Lipase & $31.69 \pm 2.11$ & $47.66 \pm 8.17$ & $29.59 \pm 3.05$ & $34.92 \pm 2.92$ \\
\hline$\alpha$-amylase & $27.69 \pm 4.71 \mathrm{a}$ & $30.72 \pm 5.11 \mathrm{a}$ & $11.76 \pm 4.20 \mathrm{~b}$ & $20.21 \pm 4.07 \mathrm{ab}$ \\
\hline $\begin{array}{l}\text { Alkaline } \\
\text { phosphatases }\end{array}$ & $2335.9 \pm 98.0 \mathrm{a}$ & $2118.1 \pm 213.0 \mathrm{~b}$ & $1124.2 \pm 34.1 .0 \mathrm{c}$ & $1495.0 \pm 110.70 \mathrm{~b}$ \\
\hline
\end{tabular}

"Leucine aminopeptidase. Values are mean \pm standard deviation $(n=6)$. Different superscript letters within rows indicate significant $(P<0.05)$ differences.

On the other hand, gene expression of $i l-10$ showed significant differences between all treatments $(P<$ $0.05)$, where all yeast supplemented treatments showed down-regulation in the liver (Fig. 1A) and intestine (Fig. 1B) with increasing yeast level dose; however, spleen showed up-regulation only in fish fed D1 (Fig. 1C). The $b 2 m$ gene expression showed significant differences between all treatments $(P<0.05)$, where fish fed yeast supplemented diets treatments had down-regulation in the liver (Fig. 2A) and intestine (Fig. 2B), but in the spleen, the increment of yeast dose showed up-regulation in fish fed D3 (Fig. 2C). Finally, gene expression of $\operatorname{tg} f-\beta 1$ showed that fish fed yeast supplemented treatments showed down-regulation in the liver (Fig. 3A) and intestine (Fig. 3B) $(P<0.05)$; nevertheless, when increasing yeast dose, the spleen (Fig. 3C) did not show significant differences between treatments $(P>0.05)$. 

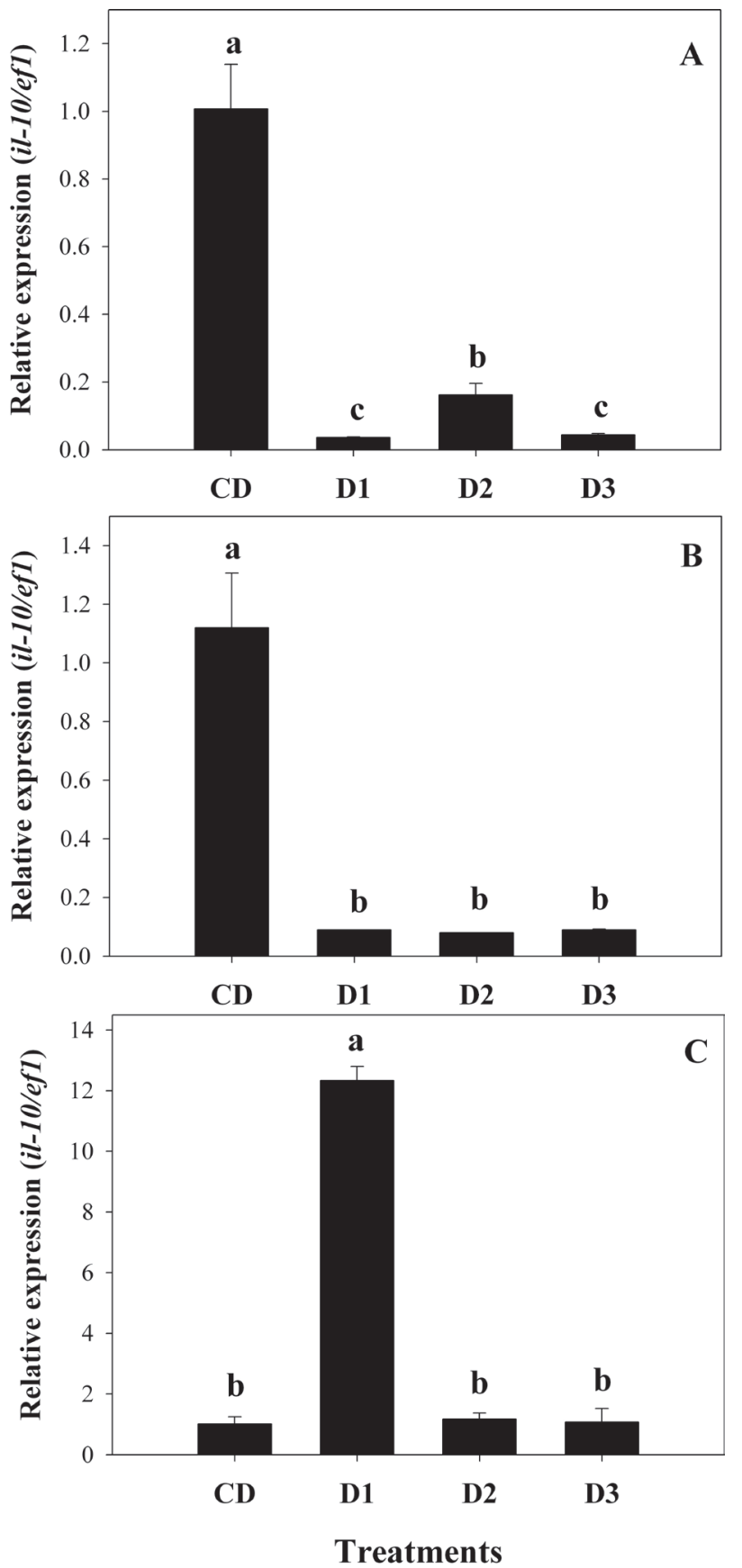

Figure 1. Relative expression of $i l-10$ in liver (1A) intestine (1B) and spleen (1C) of Atractosteus tropicus juveniles fed with experimental diets supplemented with Debaryomyces hansenii. Values are mean \pm standard deviation $(n=4)$. Different superscript letters indicate significant $(P<0.05)$.

\section{Discussion}

During the feeding trial, $A$. tropicus juveniles fed CD, and D1 showed the same DWG and SGR. In this regard, the incorporation of yeast $D$. hansenii had no positive effect on growth, including the dose of $0.5 \%\left(10^{14} \mathrm{CFU} \mathrm{g} \mathrm{diet}{ }^{-1}\right)$. Meanwhile, higher doses of $D$. hansenii (1.0 and $1.5 \%$, $10^{15}$ and $10^{16} \mathrm{CFU}$ g diet ${ }^{-1}$ ) could be highly excessive than $0.5 \%$, which was reflected in some parameters such as
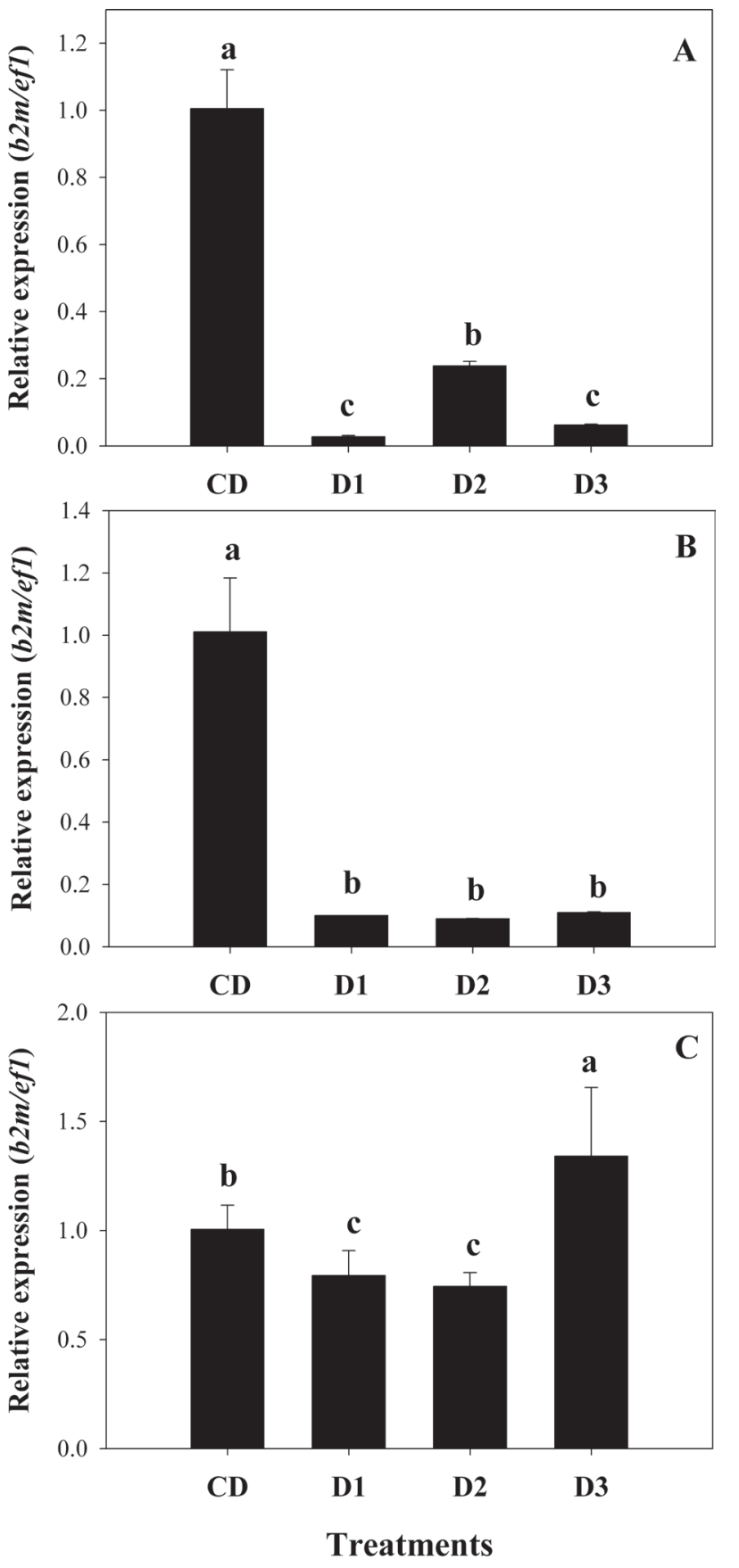

Figure 2. Relative expression of $b 2 m$ in liver (2A) intestine (2B) and spleen (2C) of Atractosteus tropicus juveniles fed with experimental diets supplemented with Debaryomyces hansenii. Values are mean \pm standard deviation $(n=4)$. Different superscript letters indicate significant $(P<0.05)$.

productive values (FCR and PER), somatic indexes (HSI, VSI, CF, and MSI) and digestive enzymes (acid and alkaline proteases, trypsin and chymotrypsin). It is well known that probiotics' positive effect depends on the concentration (Tovar-Ramírez et al. 2004). However, the appropriate concentration of probiotic levels depends on the probiotic type, fish species, physiological status, rearing conditions, and the specific goal of the applications, where $10^{5} \mathrm{CFU} \mathrm{mL} \mathrm{m}^{-1}$ is commonly accepted probiotic density (Hai 2015). Nevertheless, reports in rainbow trout, Oncorhynchus mykiss 

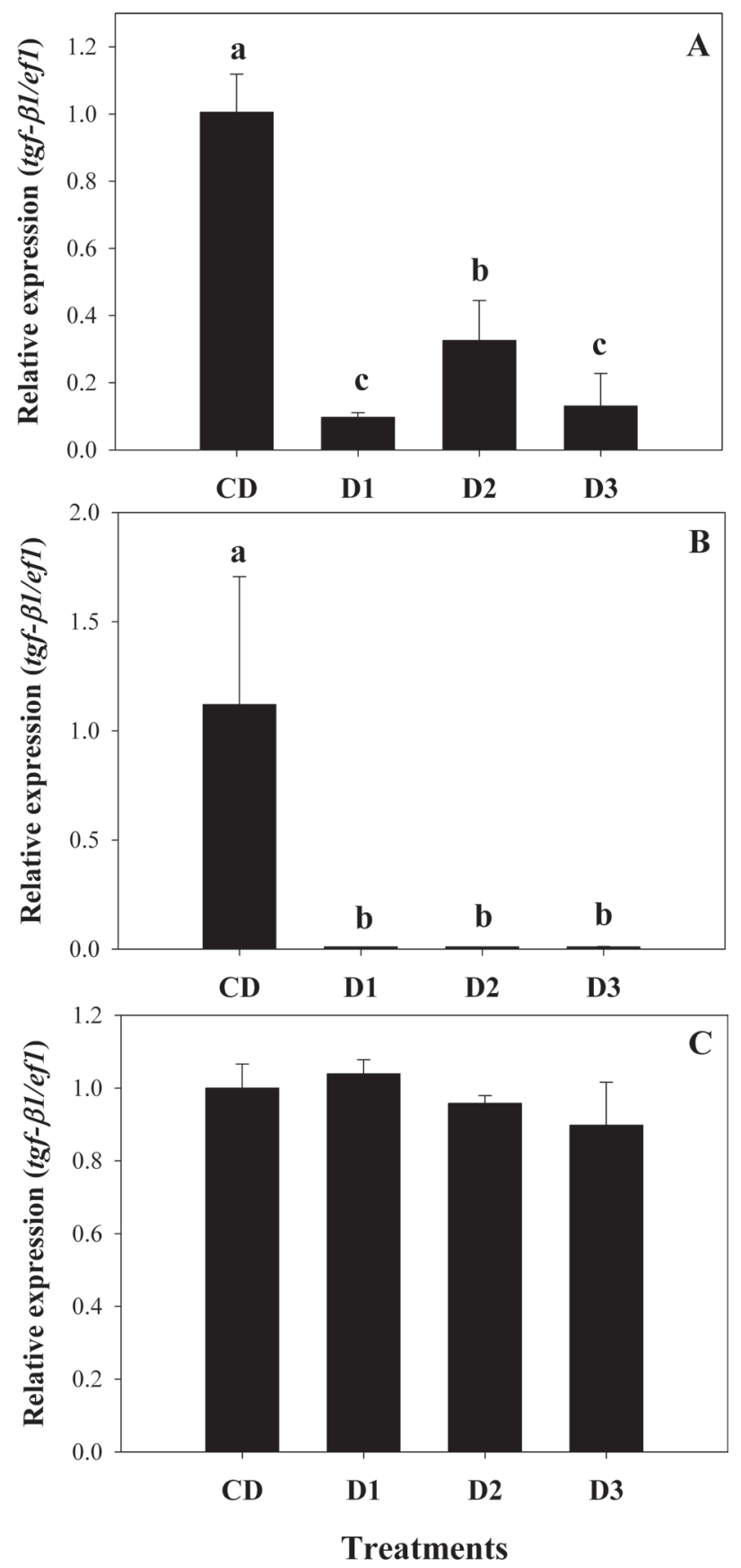

Figure 3. Relative expression of $\operatorname{tgf}-\beta 1$ in liver (3A) intestine (3B) and spleen (3C) of Atractosteus tropicus juveniles fed with experimental diets supplemented with Debaryomyces hansenii. Values are mean \pm standard deviation $(n=4)$. Different superscript letters indicate significant $(P<0.05)$.

(Walbaum, 1792), fed a probiotic (Lactobacillus rhamnosus) diet in a range of $10^{9}$ or $10^{11} \mathrm{CFU} \mathrm{g}^{-1}$, that can be considered as high doses, showed benefits on head kidney leukocyte phagocytic activity and improved serum lysozyme and alternative complement activity in a group that received

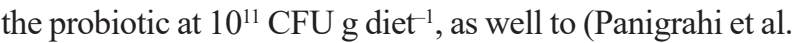
2004). Nevertheless, to our knowledge, doses of live yeast as a probiotic over $10^{14} \mathrm{CFU} \mathrm{g} \mathrm{diet}^{-1}$ are not still reported.

As characteristics, D. hansenii shows high adherence to fish gut mucosa (Tovar et al. 2002), being part of the two main microbes of the microbiome core of wild and reared carnivore marine fishes, regardless of host species, domestication status, geographic location, and water salinity (Raggi et al. 2014). Our study showed that trypsin, chymotrypsin, LAP, and $\alpha$-amylase had high activities in $A$. tropicus feed control diet and $0.5 \% D$. hansenii, compared with higher inclusion (1.0 and 1.5\%). Although it should be noted that the inclusion of $0.5 \%$ yeast was not statistically different from fish fed the control diet, it is observed that the digestive enzyme activities in fish supplemented with $0.5 \%$ $D$. hansenii are slightly higher than the control treatment. Furthermore, $D$. hansenii is associated with high production of polyamines (spermine, spermidine, and putrescine), considered as natural growth factors (Bardócz et al. 1993). Even polyamines play a role in promoting intestinal maturation and increasing the ability of enterocytes to absorb nutrients, in high concentrations decrease the absorption of nutrients (Sousadias and Smith 1995; Tovar et al. 2002, Tovar-Ramírez et al. 2004), where polyamines enter to enterocytes and induce a hormonal cascade that affects pancreas and liver (Peulen et al. 2000). As previously reported in $D$. labrax larvae, a low performance by feed high dose inclusion of $D$. hansenii is related to the high release of polyamines in the intestinal lumen (Tovar-Ramírez et al. 2004).

The beneficial effects of probiotics are consequences of several microbe properties, associated with the immune stimulation by providing molecules such as $\beta$-glucans, chitins, mannans, polyamines, among others (Akhter et al. 2015; Angulo et al. 2020), the production of inhibitory compounds that compete against pathogens bacteria for nutrients and adhesion sites and improving the microbial balance (Reyes-Becerril et al. 2017). These properties have been demonstrated in fish aquaculture, for example, cytokines as protein mediators contribute to cell growth, differentiation, and defense mechanisms of the host, where probiotics can modulate pro-inflammatory cytokines such as IL-10 and TGF- $\beta 1$ in many species (Munir et al. 2016; Román et al. 2013). Accordingly, the liver and intestine showed a down-regulated effect of $i l-10$ and $\operatorname{tg} f-\beta 1$ with yeast's inclusion; however, il-10 expression was up-regulated in the spleen for A. tropicus feed $0.5 \%$ live yeast. Therefore, down-regulation of $i l-10$ and $\operatorname{tg} f-\beta 1$ for fish feed 1.0 and $1.5 \%$ of live yeast corresponds to a negative effect to protect cells from an eventual inflammatory response (Kokou et al. 2015). On the other hand, $b 2 m$ is involved in antigen presentation for the production of antibodies and has been reported to be regulated by diet composition (Murray et al. 2010). In our experiment, this gene was down-regulated in the liver and intestine and up-regulated in the spleen in $A$. tropicus feed $0.5 \%$. Therefore, down-regulation could indicate the immune system's low ability to act against antigens (Kokou et al. 2015); however, this aspect should be verified by pathogen challenge in $A$. tropicus.

We hypothesize that incorporation of high dietary doses of D. hansenii $\left(10^{14}, 10^{15}\right.$, and $\left.10^{16} \mathrm{UFC} \mathrm{g} \mathrm{diet}^{-1}\right)$ in diets for A. tropicus juveniles promote hyper colonization in the digestive tract with the concomitant high production of polyamines and the adverse effects on 
growth, pancreatic and intestinal enzyme activities, as well as an immune-suppression of the immune systems (Tovar-Ramírez et al. 2004; Hai 2015). In this sense, fish feed at $0.5 \%\left(10^{14} \mathrm{UFC} \mathrm{g} \operatorname{diet}^{-1}\right)$ of $D$. hansenii had better performance than fish feed higher doses; however, this dose of yeast cannot be recommended for the culture of A. tropicus either. Other studies, such as adherence bioassays and histological analyses of target tissues, clarify possible organ alterations or damage, as well as consider more immune-related gene targets.

\section{Conclusions}

Our results provide new evidence that the high inclusion of yeast D. hansenii (strain CBS 8339) $\left(10^{14}, 10^{15}\right.$, and $\left.10^{16} \mathrm{CFU} g \operatorname{diet}^{-1}\right)$ is not suitable for $A$. tropicus juveniles diet. These yeast concentrations affect growth, digestive enzymatic activity, and gene expression. For this reason, it is necessary to explore lower doses to optimize the inclusion of this probiotic and improve the growth and survival of this species.

\section{Acknowledgments}

This study was financially supported by the National Council for Science and Technology (CONACyT) by project CB-2016-01-282765 named "Study of the digestive physiology in larvae and juveniles of tropical gar (Atractosteus tropicus) based on histological, biochemical, and molecular techniques."

\section{References}

Akhter N, Wu B, Memon AM, Mohsin M (2015) Probiotics and prebiotics associated with aquaculture: A review. Fish and Shellfish Immunology 45(2): 733-741. https://doi.org/10.1016/j.fsi.2015.05.038

Alvarez-González CA, Civera-Cerecedo R, Ortíz-Galindo JL, Dumas S, Moreno-Legorreta M, Grayeb-del Alamo T (2001) Effect of dietary protein level on growth and body composition of juvenile spotted sand bass, Paralabrax maculatofasciatus, fed practical diets. Aquaculture 194(1-2): 151-159. https://doi.org/10.1016/S00448486(00)00512-3

Andlid T, Vázquez-Juárez R, Gustafsson L (1995) Yeast colonizing the intestine of rainbow trout (Salmo gairdneri) and turbot (Scophthalmus maximus). Microbial Ecology 30: 321-334. https://doi. org/10.1007/BF00171938

Angulo C, Maldonado M, Delgado K, Reyes-Becerril M (2017) Debaryomyces hansenii up regulates superoxide dismutase gene expression and enhances the immune response and survival in Pacific red snapper (Lutjanus peru) leukocytes after Vibrio parahaemolyticus infection. Developmental and Comparative Immunology 71: 18-27. https://doi.org/10.1016/j.dci.2017.01.020

Angulo M, Reyes-Becerril M, Medina-Cordova N, Tovar-Ramírez D, Angulo C (2020) Probiotic and nutritional effects of Debaryomyces hansenii on animals. Applied Microbiology and Biotechnology 104(18): 7689-7699. https://doi.org/10.1007/s00253-020-10780-z

Anson ML (1938) The estimation of pepsin, trypsin, papain and cathepsin with hemoglobin. Journal of General Physiology 22(1): 79-89. https://doi.org/10.1085/jgp.22.1.79

Bardócz S, Grant G, Brown DS, Ralph A, Pusztai A (1993) Polyamines in food-Implications for growth and health. Journal of $\mathrm{Nu}-$ tritional Biochemistry 4(2): 66-71. https://doi.org/10.1016/09552863(93)90001-D

Bergmeyer HU (1974) Phosphatases: Methods of enzymatic analysis. Vol 2. Academic Press, New York, USA, 1196-1201. https://doi. org/10.1016/B978-0-12-091304-6.X5001-0

Bradford MM (1976) A rapid and sensitive method for the quantitation of microgram quantities of protein utilizing the principle of protein-dye binding. Analytical Biochemistry 72(1-2): 248-254. https://doi.org/10.1016/0003-2697(76)90527-3
Chen W, Gao F, Chu F, Zhang J, Gao GF, Xia C (2010) Crystal structure of a bony fish $\beta 2$-microglobulin: Insights into the evolutionary origin of immunoglobulin superfamily constant molecules. Journal of Biological Chemistry 285(29): 22505-22512. https://doi. org/10.1074/jbc.M109.095000

Erlanger B, Kokowsky N, Cohen W (1961) The preparation and properties of two new chromogenic substrates of trypsin. Archives of Biochemistry and Biophysics 95(2): 271-278. https://doi. org/10.1016/0003-9861(61)90145-X

Flajnik MF, Kasahara M (2001) Comparative genomics of the MHC: Glimpses into the evolution of the adaptive immune system. Immunity 15(3): 351-362. https://doi.org/10.1016/S1074-7613(01)00198-4 Frías-Quintana CA, Márquez-Couturier G, Alvarez-González CA, Tovar-Ramírez D, Nolasco-Soria H, Galaviz-Espinosa MA, Gisbert E (2015) Development of digestive tract and enzyme activities during the early ontogeny of the tropical gar Atractosteus tropicus. Fish Physiology and Biochemistry 41(5): 1075-1091. https://doi. org/10.1007/s10695-015-0070-9

Frías-Quintana CA, Domínguez-Lorenzo J, Alvarez-González CA, Tovar-Ramírez D, Martínez-García R (2016) Using cornstarch in microparticulate diets for larvicultured tropical gar (Atractosteus tropicus). Fish Physiology and Biochemistry 42(2): 517-528. https://doi. org/10.1007/s10695-015-0156-4

Frías-Quintana CA, Alvarez-González CA, Tovar-Ramírez D, MartínezGarcía R, Camarillo-Coop S, Peña E, Galaviz M (2017) Use of potato starch in diets of tropical gar (Atractosteus tropicus, Gill 1863) larvae. Fishes 2(1): 3. https://doi.org/10.3390/fishes2010003

Guerrero-Zárate R, Alvarez-González CA, Olvera-Novoa MA, Perales-García N, Frías-Quintana CA, Martínez-García R, Contreras-Sánchez WM (2014) Partial characterization of digestive proteases in tropical gar Atractosteus tropicus juveniles. Fish Physiology and Biochemistry 40: 1021-1029. https://doi.org/10.1007/s10695-013-9902-7 Hai NV (2015) The use of probiotics in aquaculture. Journal of Applied Microbiology 119(4): 917-935. https://doi.org/10.1111/jam.12886

Howes A, Gabryšová L, O'Garra A (2014) Role of IL-10 and the IL-10 Receptor in Immune Responses. In: Reference module in biomedical sciences, Elsevier. https://doi.org/10.1016/B978-0-12-801238-3.00014-3 
Hummel BCW (1959) A modified spectrophotometric determination of chymotrypsin, trypsin and thrombin. Canadian Journal of Biochemistry and Physiology 37(12): 1393-1399. https://doi.org/10.1139/ o59-157

Jiménez-Martínez LD, Álvarez-González CA, De la Cruz-Hernández E, Tovar-Ramírez D, Galaviz MA, Camarillo-Coop S, Martínez-García R, Concha-Frías B, Peña E (2019) Partial sequence characterization and ontogenetic expression of genes involved in lipid metabolism in the tropical gar (Atractosteus tropicus). Aquaculture Research 50(1): 162-172. https://doi.org/10.1111/are.13879

Kokou F, Sarropoulou E, Cotou E, Rigos G, Henry M, Alexis M, Kentouri M (2015) Effects of fish meal replacement by a soybean protein on growth, histology, selected immune and oxidative status markers of gilthead sea bream, Sparus aurata. Journal of the World Aquaculture Society 46(2): 115-128. https://doi.org/10.1111/jwas.12181

Li Z, Zhang N, Ma L, Zhang L, Meng G, Xia C (2020) The mechanism of $\beta 2 \mathrm{~m}$ molecule-induced changes in the peptide presentation profile in a bony fish. iScience 23: 101119. https://doi.org/10.1016/j. isci.2020.101119

Livak KJ, Schmittgen TD (2001) Analysis of relative gene expression data using real-time quantitative PCR and the $2-\Delta \Delta C T$ method. Methods (San Diego, Calif.) 25(4): 402-408. https://doi. org/10.1006/meth.2001.1262

Maroux S, Louvard D, Baratti J (1973) The aminopeptidase from hog-intestinal brush border. Biochimica et Biophysica Acta 321(1): 282-295. https://doi.org/10.1016/0005-2744(73)90083-1

Márquez-Couturier G, Vázquez-Navarrete CJ (2015) Estado del arte de la biología y cultivo de pejelagarto (Atractosteus tropicus). Agroproductividad 8(8): 44-51.

Martínez-Burguete T, Peña-Marín ES, García-Gasca A, Alvarez-González CA, Llera-Herrera R (2021) Nutrigenomic marker discovery by de novo transcriptomic sequencing during early development of the tropical gar (Atractosteus tropicus). Aquaculture Research are.15228. https://doi.org/10.1111/are.15228

Munir MB, Hashim R, Chai YH, Marsh TL, Nor SAM (2016) Dietary prebiotics and probiotics influence growth performance, nutrient digestibility and the expression of immune regulatory genes in snakehead (Channa striata) fingerlings. Aquaculture (Amsterdam, Netherlands) 460: 59-68. https://doi.org/10.1016/j.aquaculture.2016.03.041

Murray HM, Lall SP, Rajaselvam R, Boutilier LA, Blanchard B, Flight RM, Colombo S, Mohindra V, Douglas SE (2010) A nutrigenomic analysis of intestinal response to partial soybean meal replacement in diets for juvenile Atlantic halibut, Hippoglossus hippoglossus, L. Aquaculture 298(3-4): 282-293. https://doi.org/10.1016/j.aquaculture.2009.11.001

Nájera-Arzola I, Alvarez-González CA, Frías-Quintana CA, Peña E, Martínez-García R, Camarillo-Coop S, Méndez-Marín O, Gisbert E (2018) Evaluation of mannan oligosaccharides (MOS) in balanced diets for tropical gar juveniles (Atractosteus tropicus). Hidrobiológica 28(3): 239-246. https://doi.org/10.24275/uam/izt/dcbs/ hidro/2018v28n3/Pena

Navarrete P, Tovar-Ramírez D (2014) [Chapter 5] Use of yeasts as probiotics in fish aquaculture. Pp 135-172. In: Hernandez-Vergara M, Perez-Rostro C (Eds) Sustainable aquaculture techniques. IntechOpen Limited, London, UK. https://doi.org/10.1016/B978-0-12801238-3.00014-3
Nieves-Rodríguez K, Alvarez-González CA, Peña-Marín E, Vega-Villasante F, Martínez-García R, Camarillo-Coop S, Gisbert E (2018) Effect of $\beta$-glucans in diets on growth, survival, digestive enzyme activity, and immune system and intestinal barrier gene expression for tropical gar (Atractosteus tropicus) juveniles. Fishes 3(3): 27. https://doi.org/10.3390/fishes3030027

Panigrahi A, Kiron V, Kobayashi T, Puangkaew J, Satoh S, Sugita H (2004) Immune responses in rainbow trout Oncorhynchus mykiss induced by a potential probiotic bacteria Lactobacillus rhamnosus JCM 1136. Veterinary Immunology and Immunopathology 102(4): 379-388. https://doi.org/10.1016/j.vetimm.2004.08.006

Peulen O, Deloyer P, Grandfils C, Loret S, Dandrifosse G (2000) Intestinal maturation induced by spermine in young animals. Livestock Production Science 66(2): 109-120. https://doi.org/10.1016/S03016226(00)00218-9

Qi P, Xie C, Guo B, Wu C (2016) Dissecting the role of transforming growth factor- $\beta 1$ in topmouth culter immunobiological activity: A fundamental functional analysis. Scientific Reports 6(1): 27179. https://doi.org/10.1038/srep27179

Raggi P, Lopez P, Diaz A, Carrasco D, Silva A, Velez A, Navarrete PA (2014) Debaryomyces hansenii and Rhodotorula mucilaginosa comprised the yeast core gut microbiota of wild and reared carnivorous salmonids, croaker and yellowtail. Environmental Microbiology 16(9): 2791-2803. https://doi.org/10.1111/14622920.12397

Reyes-Becerril M, Salinas I, Cuesta A, Meseguer J, Tovar-Ramirez D, Ascencio-Valle F, Esteban MÁ (2008) Oral delivery of live yeast Debaryomyces hansenii modulates the main innate immune parameters and the expression of immune-relevant genes in the gilthead seabream (Sparus aurata L.). Fish and Shellfish Immunology 25(6): 731-739. https://doi.org/10.1016/j.fsi.2008.02.010

Reyes-Becerril M, Tovar-Ramírez D, Ascencio-Valle F, Civera-Cerecedo R, Gracía-López V, Barbosa-Solomieu V, Esteban MA (2011) Effects of dietary supplementation with probiotic live yeast Debaryomyces hansenii on the immune and antioxidant systems of leopard grouper Mycteroperca rosacea infected with Aeromonas hydrophila. Aquaculture Research 42(11): 1676-1686. https://doi.org/10.1111/ j.1365-2109.2010.02762.x

Reyes-Becerril M, Guluarte C, Ceballos-Francisco D, Angulo C, Esteban MÁ (2017) Dietary yeast Sterigmatomyces halophilus enhances mucosal immunity of gilthead seabream (Sparus aurata L.). Fish and Shellfish Immunology 64: 165-175. https://oi.org/10.1016/j. fsi.2017.03.027

Robyt JF, Whelan W (1968) Starch and its Derivates. Pp 423-429. In: Radley JA (Ed.) Starch and its Derivates. Chapman and Hall. London, UK, 528 pp. https://doi.org/10.1002/star.19700220208

Román L, Real F, Padilla D, El-Aamri F, Déniz S, Grasso V, Acosta F (2013) Cytokine expression in head-kidney leucocytes of European sea bass (Dicentrarchus labrax L.) after incubation with the probiotic Vagococcus fluvialis L-21. Fish and Shellfish Immunology 35(4): 1329-1332. https://doi.org/10.1016/j.fsi.2013.07.036

Saenz de Rodrigáñez M, Aguilar-Tellez FV, Alarcón-López FJ, Pedrosa-Islas R, Peña-Marín ES, Martínez-García R, Guerrero-Zárate R, Matamoros WA, Alvarez-González CA (2018) Evaluation of microencapsulated diets for tropical gar (Atractosteus tropicus) larviculture. Revista de Biología Tropical 66(3): 1298-1313. https://doi. org/10.15517/rbt.v66i3.31727 
Sharifuzzaman SM, Austin B (2017) Probiotics for disease control in aquaculture. Pp. 189-222. In: Austin B, Newaj-Fyzul A (Eds.) Diagnosis and control of diseases of fish and shellfish. John Wiley and Sons, Hoboken, NJ, USA, 320 pp. https://doi. org/10.1002/9781119152125.ch8

Sousadias MG, Smith TK (1995) Toxicity and growth-promoting potential of spermine when fed to chicks. Journal of Animal Science 73(8): 2375-2381. https://doi.org/10.2527/1995.7382375x

Tovar D, Zambonino-Infante JL, Cahu C, Gatesoupe FJ, Vázquez-Juárez R, Lésel R (2002) Effect of live yeast incorporation in compound diet on digestive enzyme activity in sea bass (Dicentrarchus labrax) larvae. Aquaculture 204(1-2): 113-123. https://doi.org/10.1016/ S0044-8486(01)00650-0

Tovar-RamírezD, Zambobino-Infante JL, Cahu C, Gatesoupe FJ, VazquezJuárez R (2004) Influence of dietary live yeast on European sea bass (Dicentrarchus labrax) larval development. Aquaculture 234(1-4): 415-427. https://doi.org/10.1016/j.aquaculture.2004.01.028
Tovar-Ramírez D, Mazurais D, Gatesoupe JF, Quazuguel P, Cahu C, Zambonino-Infante JL (2010) Dietary probiotic live yeast modulates antioxidant enzyme activities and gene expression of sea bass ( $D i$ centrarchus labrax) larvae. Aquaculture 300(1-4): 142-147. https:// doi.org/10.1016/j.aquaculture.2009.12.015

Versaw W, Cuppett SL, Winters DD, Williams LE (1989) An improved colorimetric assay for bacterial lipase in nonfat dry milk. Journal of Food Science 54(6): 232-254. https://doi. org/10.1111/j.1365-2621.1989.tb05159.x

Walter HE (1984) Proteinases: Methods with hemoglobin, casein and azocoll as substrates. Pp. 270-277. In: Bergmeyern HJ (Ed.) Methods of enzymatic analysis. Verlag Chemie, Weinheim, Germany, 1064 pp.

Wang Y, Wang S, Luo H, Lv Y (2017) Transforming growth factor $\beta 1$ gene play a novel role in innate immune response in Pelteobagrus fulvidraco. Turkish Journal of Fisheries and Aquatic Sciences 18: 539-546. https://doi.org/10.4194/1303-2712-v18_4_05 